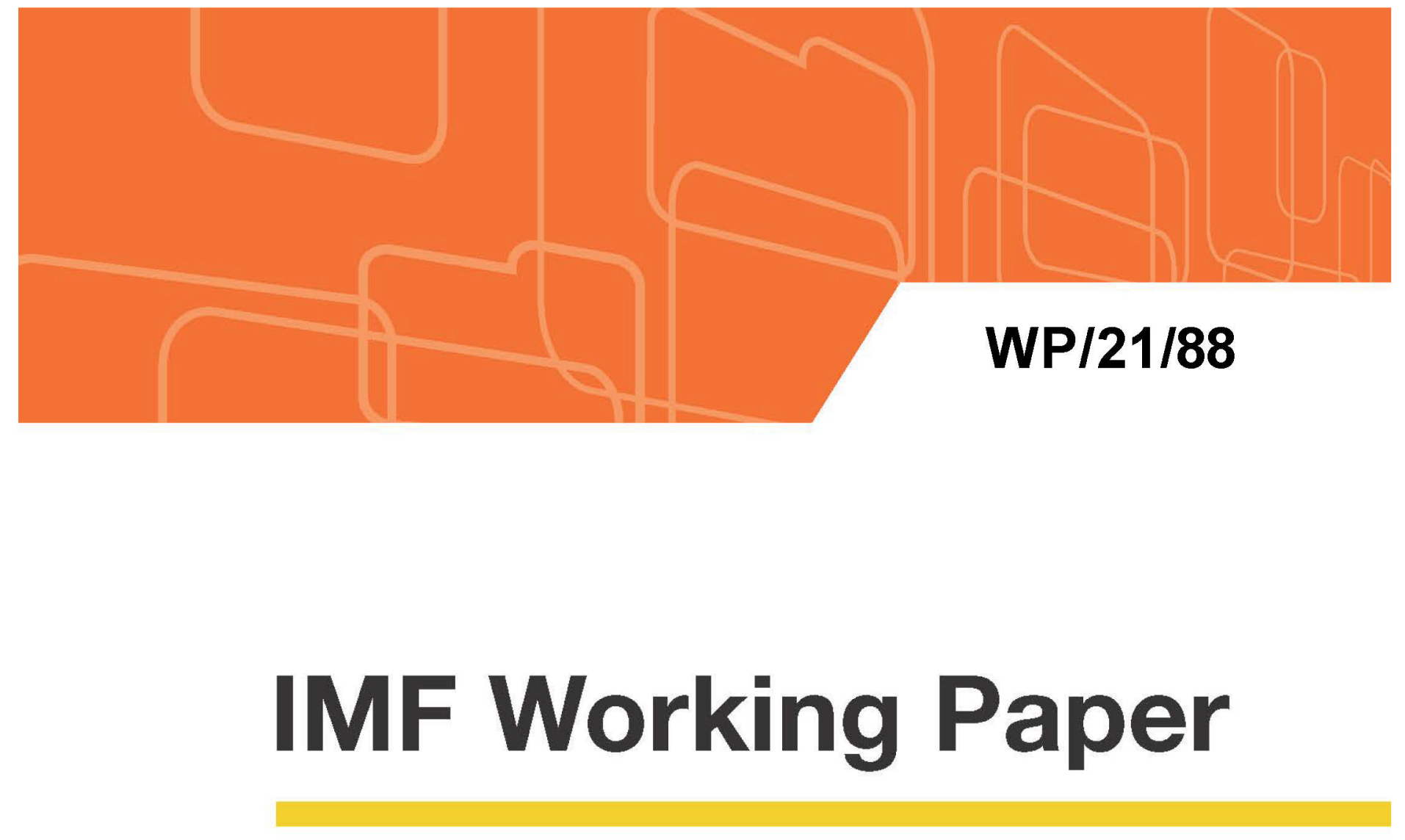

\title{
The Impact of International Migration on Inclusive Growth:
} A Review

by Zsoka Koczan, Giovanni Peri, Magali Pinat, and Dmitriy Rozhkov

IMF Working Papers describe research in progress by the author(s) and are published to elicit comments and to encourage debate. The views expressed in IMF Working Papers are those of the author(s) and do not necessarily represent the views of the IMF, its Executive Board, or IMF management. 


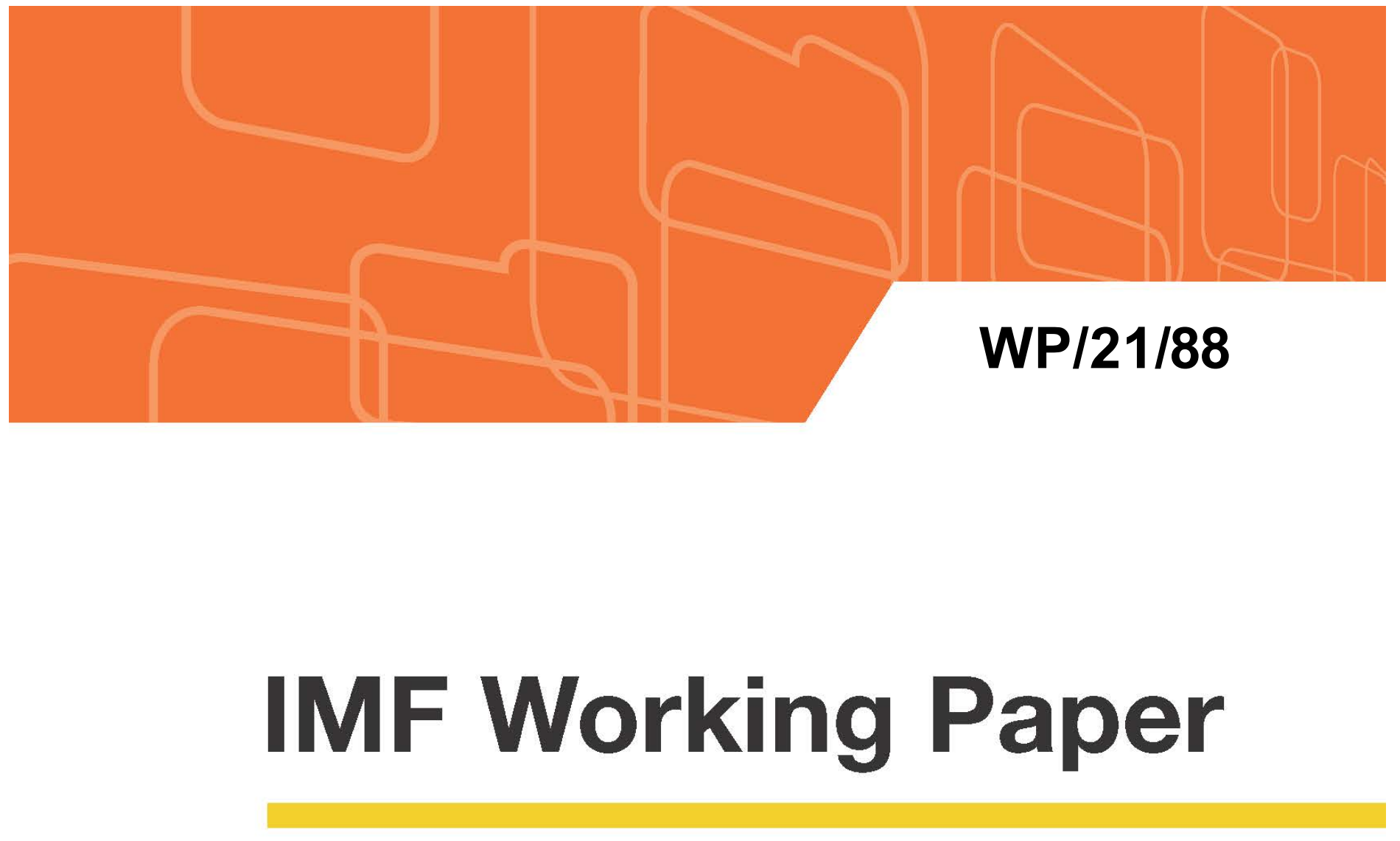

\section{The Impact of International Migration on Inclusive Growth:} A Review

by Zsoka Koczan, Giovanni Peri, Magali Pinat, and Dmitriy Rozhkov

IMF Working Papers describe research in progress by the author(s) and are published to elicit comments and to encourage debate. The views expressed in IMF Working Papers are those of the author(s) and do not necessarily represent the views of the IMF, its Executive Board, or IMF management.

I N T E R N A T I O N A L M O N E T A R Y F U N D 
IMF Working Paper

Institute for Capacity Development

The Impact of International Migration on Inclusive Growth: A Review ${ }^{1}$

Prepared by Zsoka Koczan, Giovanni Peri, Magali Pinat, and Dmitriy Rozhkov

Authorized for distribution by Valerie Cerra

March 2021

IMF Working Papers describe research in progress by the author(s) and are published to elicit comments and to encourage debate. The views expressed in IMF Working Papers are those of the author(s) and do not necessarily represent the views of the IMF, its Executive Board, or IMF management.

\begin{abstract}
International migration is an important channel of material improvement for individuals and their offspring. The movement of people across country borders, especially from less developed to richer countries, has a substantial impact in several dimensions. First, it affects the migrants themselves by allowing them to achieve higher income as a result of their higher productivity in the destination country. It also increases the expected income for their offspring. Second, it affects the destination country through the impact on labor markets, productivity, innovation, demographic structure, fiscal balance, and criminality. Third, it can have a significant impact on the countries of origin. It may lead to loss of human capital, but it also creates a flow of remittances and increases international connections in the form of trade, FDI, and technological transfers. This paper surveys our understanding of how migration affects growth and inequality through the impact on migrants themselves as well as on the destination and origin countries.
\end{abstract}

JEL Classification Numbers: F22, O15, F63, J61

Keywords: International Migration, Inequality, Economic growth

Authors' E-Mail Addresses: KoczanZ@ebrd.com; GPeri@ucdavis.edu; MPinat@imf.org; DRozhkov@imf.org

\footnotetext{
${ }^{1}$ We thank Va lerie Cerra and Barry Eichengreen, as well as participants in the Inclusive Growth book seminar series organized by the IMF In stitute for Capacity Development for their comments. This is a draft of a chapter that has been accepted for publication by Oxford University Press in the forthcoming book titled: "How to Achieve Inclusive Growth", edited by V. Cerra, B. Eichengreen, A. El-Ga na iny, a nd M. Schindler due for publication in 2021.
} 


\section{Contents}

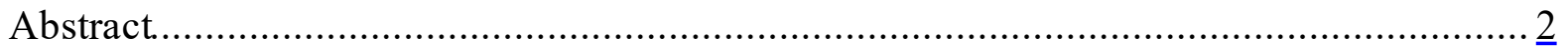

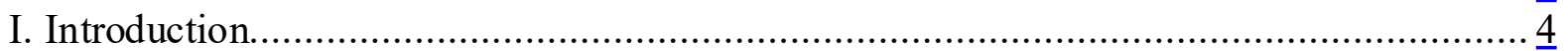

II. Consequences of migration for migrants.................................................... $\underline{6}$

III. Impact of migration on destination countries.................................................

A. Impact on the Labor Market......................................................................... 9

The substitution/complementarity effect................................................ 11

The productivity and demand effect.......................................................... $\frac{12}{12}$

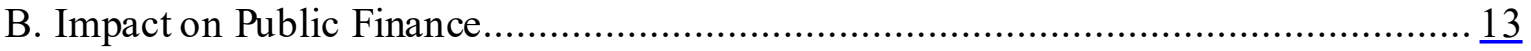

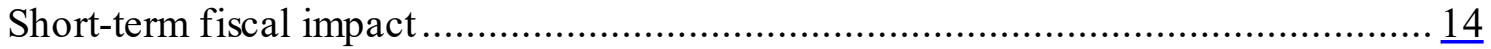

Long-term fiscal impact.................................................................. $\frac{14}{14}$

C. Impact on the incidence of crime.......................................................... $\frac{15}{16}$

D. Adopting reasonable immigration policies and fostering integration ..................... $\frac{16}{16}$

Reaping the benefits of immigration.................................................... 16

Minimizing the impact on native workers............................................... $\frac{17}{18}$

Paying special attention to refugees..................................................... $\frac{18}{19}$

IV. Impact of migration on origin countries .................................................... $\frac{19}{19}$

A. Impact on the labor market in origin countries....................................... 19

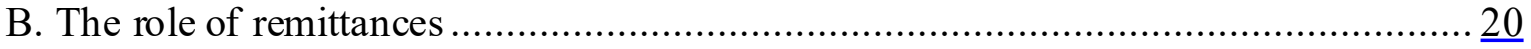

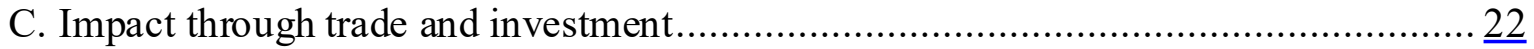

D. Costs of emigration associated with the brain drain................................... 23

E. Country Case: Kyrgyz Republic ........................................................... 24

F. Country Case: Mexico.........................................................................

G. Policies that can help the origin countries to maximize the benefits and minimize the

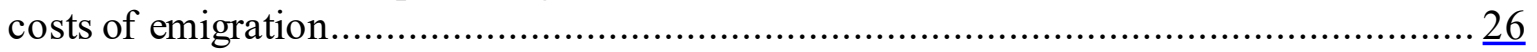

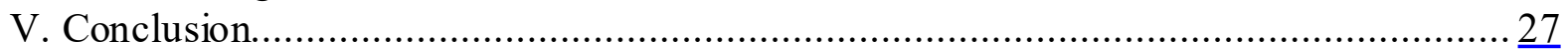

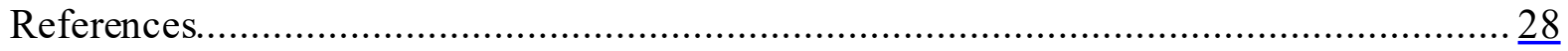

\section{Figures}

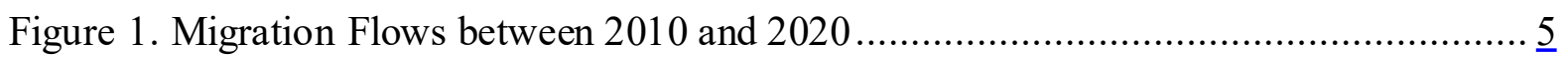

Figure 2. Relative Poverty Rates in the OECD Countries, 2015 ................................ $\underline{7}$

Figure 3. Top 20 destination economies by number of international migrants and refugees

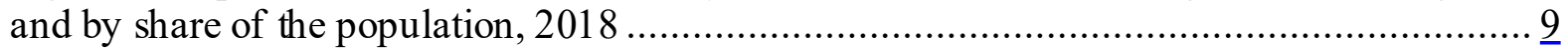

Figure 4. Share of emigrants moving intra-regionally, by world region, 2000 and $2017 \ldots \ldots \underline{19}$

Figure 5. Remittances and Income Inequality............................................ $\frac{25}{25}$

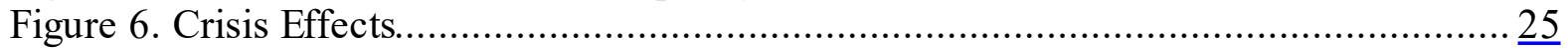

\section{Diagrams}

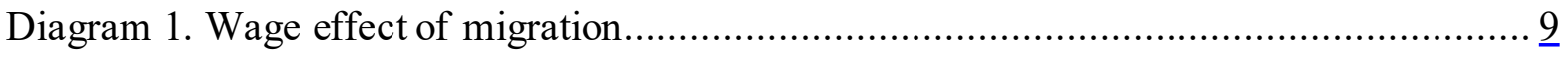

Diagram 2. The net fiscal impact of immigrants............................................. 14 


\section{INTRODUCTION}

International migration is an important channel of material improvement for individuals and their offspring ${ }^{2}$. The movement of people across country borders, especially from less developed to richer countries, has a substantial impact in several dimensions. First, it affects the migrants themselves by allowing them to achieve higher income as a result of their higher productivity in the destination country. It also increases the expected income for their offspring. Second, it affects the destination country through the impact on labor markets, productivity, innovation, demographic structure, fiscal balance, and criminality. This is due in large part to the fact that immigrants are different from natives and differentiated among themselves. Third, it can have a significant impact on the countries of origin. It may lead to loss of human capital, amplified by the fact that migration can beget more future migration (the so-called chain or network effect), but it also creates a flow of remittances and increased international connections in the form of trade FDI, and technological transfers.

The overarching purpose of this paper is to survey our understanding of how migration affects inclusive growth. To do that, we look at how it affects growth and inequality in the world through the impact on migrants themselves as well as on the destination and origin countries. Due to data limitations, the paper looks primarily at income inequality, but the impact on wealth inequality will be considered where feasible. This distinction is important because migration may have different effects on different measures of inequality at different time horizons.

It is useful to start by framing the discussion within a few important facts relative to international migration and its evolution in the last 30 years. Total migrants as a percentage of the world population have remained rather stable at around 3 percent since 1990. While a lot of attention in the media and among the politicians in recent years has focused on migration from Africa and the Middle East to Europe and North America, most migration in the world is, in fact, intra-regional (Figure 1). Large regional migration hubs have emerged in Africa (Cote d'Ivoire, South Africa), Asia (Hong Kong, Singapore), and the Middle East (GCC countries), and there is also significant migration within the European Union. The only exception is Latin America, where there is relatively little intra-regional migration (possibly because some migration, for example, from Venezuela to neighboring Colombia and Ecuador, is not captured by statistics). That said, the impact on various countries in terms of population growth has been quite different. While mobility among developing economies has grown less than their population, mobility from developing to advanced economies has significantly increased, especially as a share of the advanced economies' population (which has not increased much in the recent decades). In the last 30 years, the share of migrants from developing to advanced economies has increased from 4 to 9 percent of the population of advanced economies (IMF WEO 2020), and this has generated strong social and political reactions and increased attention to the phenomenon in most advanced countries.

\footnotetext{
${ }^{2}$ While internal migration is also a very im portant phenomenon with significanteconomic and social consequences, we focus on international movements as data for those a re more accurate, differences in economic performance between origin and destination countries are la rger and issues like la nguage barriers and human capital costs of transfer more important. For the same reason, we mention the special case of refugees, a though in many countries the internally displaced people may be equally or more important.
} 
Another important fact is that most of the increased migration from developing to advanced economies can be defined as "economic migration," meaning driven by people looking for better economic opportunities. While migration driven by wars, natural disasters, and political turmoil has increased in numbers, most of it is internal or between developing countries close to each other. Accordingly, most of the discussion in this paper refers to economic migration, although in some instances, we will note the special case of refugees and the way their impact is likely to differ from that of economic migrants.

Figure 1. Migration Flows between 2010 and 2020

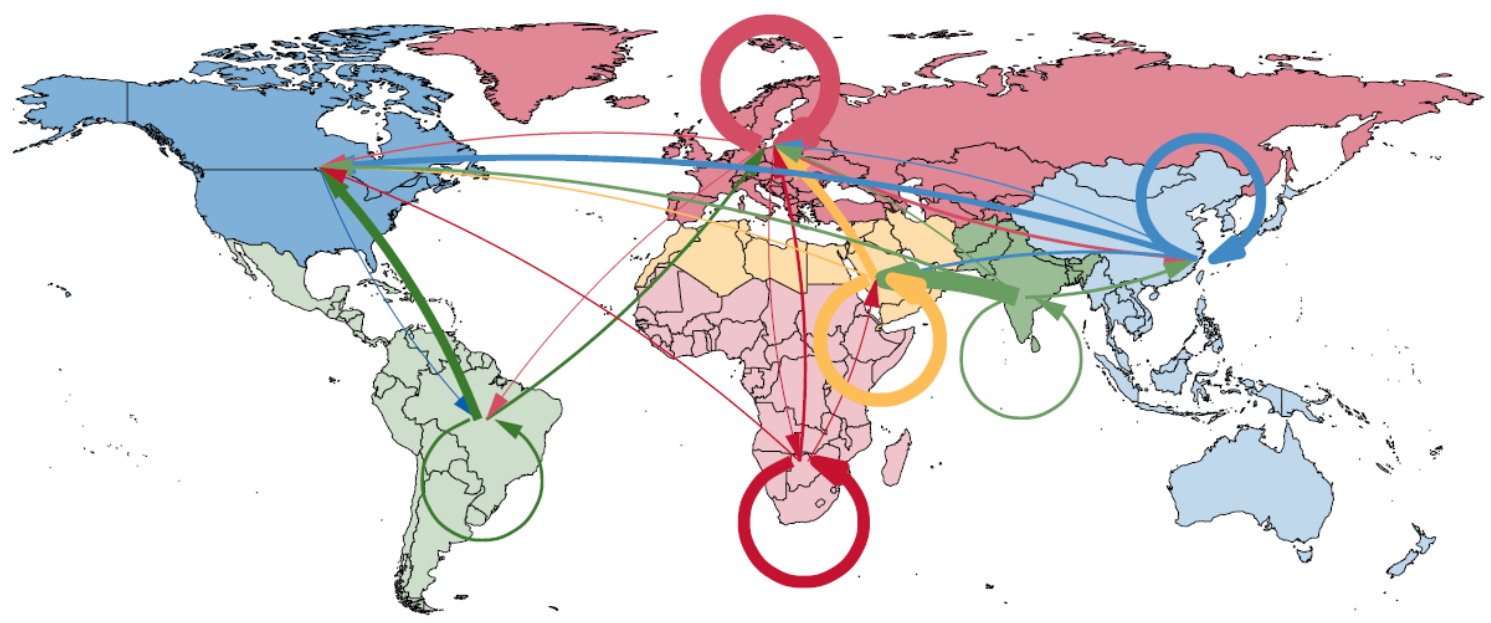

Source: $\operatorname{IMF}(2020)$

Note: Migrants a re defined as the foreign-born population in a destination region. migra tion flows larger than 200,000 people between 2010 and 2020. The width of flows is proportional to the number of migrants.

Following the common practice for most studies, we define "migrants" as individuals who are foreign-born residents of a recipient country. Consequently, we will not distinguish between permanent migrants (intending to stay in the receiving country indefinitely) and temporary migrants (those who plan to return to their country of origin). Such definitions are themselves rather arbitrary, as migrants who move to a country on a temporary basis may end up staying for long periods, while migrants who arrive as permanent may return or remigrate. We will note the instances where this distinction is likely to be important.

The ability to measure the stock and flows of migrants across countries has improved significantly in the recent decades, mainly thanks to careful work using population censuses that infer net migration from the change in stocks of people born in a country and residing in a different one. These data usually include people who are "undocumented," i.e., present in a country without a proper title for staying, as they are based on counts of resident (and not citizen) population. However, measures of gross flows of migrants, which are based on arrival records, can significantly underestimate migration due to the flows of undocumented migrants.

With this background, we will review what recent research has found in terms of the economic effects of international migration and what we have learned about policy 
instruments that can be used to manage migration to maximize its benefits for receiving and sending countries.

\section{CONSEQUENCES OF MIGRATION FOR MIGRANTS}

The decomposition of global inequality into between country and within-country inequality is sensitive to data measurement issues. But the consensus holds that within-country inequality has been rising around the world over the past several decades, while betweencountry inequality has declined moderately. Nevertheless, large and persistent gaps in mean income between countries remain. Unskilled workers' wages in rich and poor countries often differ by a factor of 10 to 1 . This substantial difference in incomes between countries is certainly the main driver of economic migration.

As a consequence, many migrants experience a large increase in income when they move to richer economies. Clemens, Montenegro, and Pritchett (2019) estimate the real (purchasing power parity, PPP) wage gaps between immigrants in the United States and their observably equivalent national counterparts in 42 home labor markets in developing countries. They calculate the average lower bound on this wage ratio (weighted by the working-age (15-49) population of the home countries) to be 5.7. This ratio exceeds 16 for some developing countries in the sample. There is, therefore, a very large potential monetary gain from migration.

The gains from migration are larger the younger the migrant is because younger migrants have a longer lifetime ahead of them to benefit from the extra income; hence the present discounted gains from migration are higher (IMF, $2020 \mathrm{WEO}$ ). Other factors include the level of education and skills that are in high demand in the destination countries. These factors drive the selection of people who migrate, with younger, more educated, and more skilled individuals being among those with a higher probability of emigration. Large potential monetary gains have developed an industry around migration, with recruiting firms and brokers engaging in fraudulent and abusive practices. Better regulating the migration industry would protect migrants' workers from exploitation and substantial loss of savings and assets (World Bank, 2014). 
At the same time, the ability to integrate with the receiving country is a key element of whether migrants are able to fully realize the potential gains from migration. Figure 2, taken from OECD (2018), shows that in the EU and in other OECD countries, migrants tend to have much higher poverty rates than the native population. OECD (2018) also shows that they are more likely to be unemployed or overqualified in their jobs, more likely to live in overcrowded housing, have worse health outcomes and worse education outcomes for their children compared to natives. The ability of migrants to assimilate depends on their origin, skills, and characteristics (Ho and TurkHariss, 2018; Abramitzky et al., 2019). In many OECD countries, immigrants report high levels of discrimination and abuse based on their nationality, ethnicity, or race.

While discrimination and prejudice leading to incomplete integration are significant hurdles to the economic success of immigrants, the revealed preference argument suggests that, in most cases, by moving and remaining in the destination country, migrants are willing to

Figure 2. Relative Poverty Rates in the OECD Countries, 2015

(Percentages of the population aged 16 years and over, 2015)

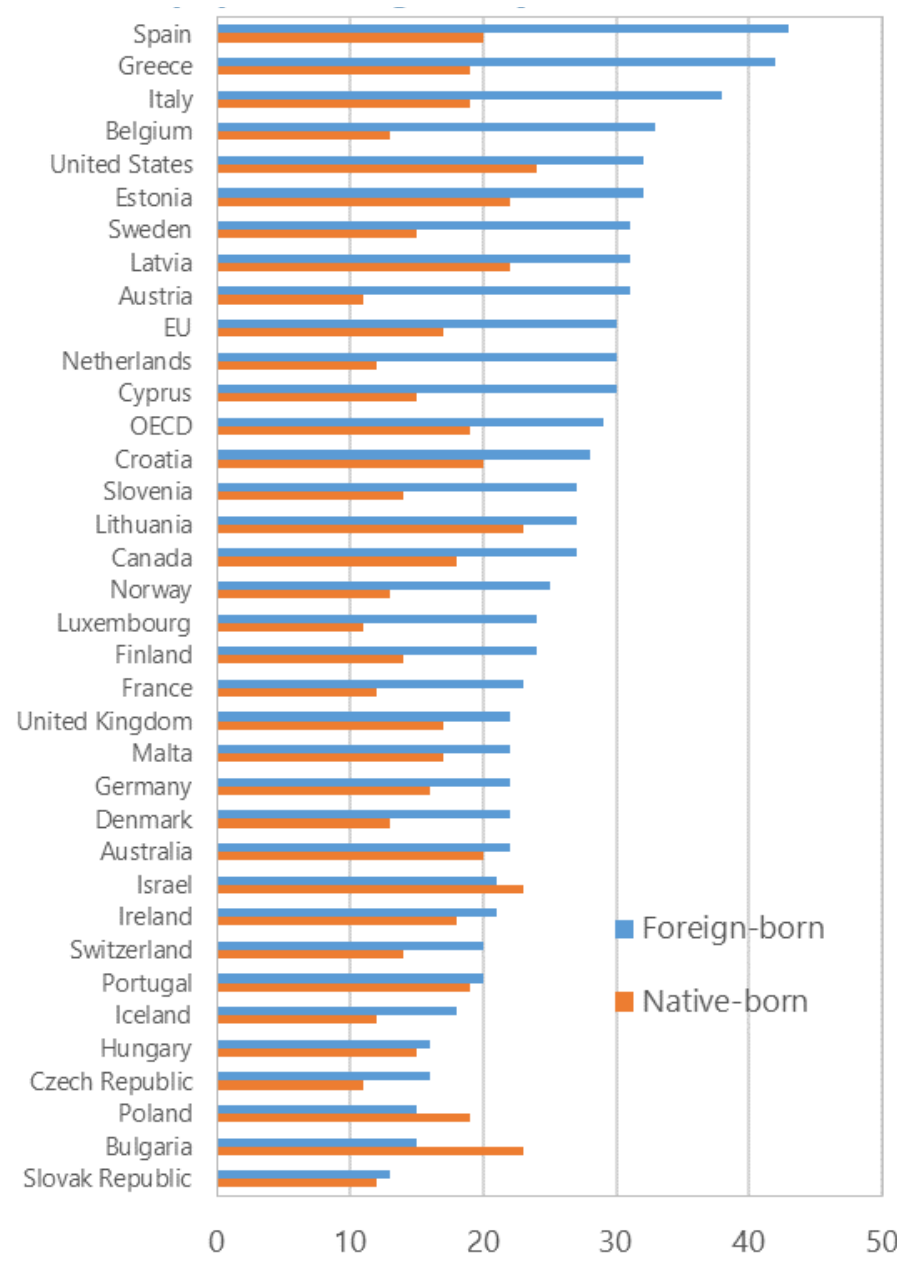

Source: OECD 2018 withstand these difficulties in order to achieve the significant income gain. In this respect, refugees are different in that for this group; the gains are more likely to take the form of escape and safety from violence, persecution, and famine.

The decision to return to their home country is quite common among emigrants. However, the rate of return depends, among other things, on the destination country, with a substantially higher rate of return from European destinations compared with Australia, Canada, New Zealand, and the United States. The time spent in the destination country is also an important factor in the decision to return. Return migration rates are highest during the first decade from arrival and then level off (Dustmann and Görlach, 2016). Some migrants decide to return to their home country because they did not achieve the success they anticipated in terms of employment, wages, or quality of life. For other migrants, the decision to return can be part of the initial strategy: migrants move temporarily to accumulate savings and human capital and return to their home country to benefit from it. Barrett and Goggin 
(2010) find that wage premia affect Mexican, Albanian, Hungarian, and Irish migrants' decision to return. Dustmann (1996) and Dustmann and Görlach (2016) develop theoretical models of temporary migration in which migrants are working abroad acquire additional skills that are rewarded in the home country.

\section{IMPACT OF MIGRATION ON DESTINATION COUNTRIES}

International migration is both a challenge and an opportunity for destination countries. On the one hand, especially in the short run, immigrants can create challenges in local labor markets, potentially affecting wages and displacing some native workers who compete with them. Their arrival may also impose a short-term fiscal cost. On the other hand, especially in the medium and long run, immigrants can boost output, create new opportunities for local firms and native workers, supply abilities and skills needed for growth, generate new ideas, stimulate international trade and contribute to long-term fiscal balance, by making the age distribution of advanced countries more balanced. Moreover, both in the short and long run, different groups (high or low educated workers, owners of capital, owners of houses, young or old individuals) may benefit to a different extent from the inflow of immigrants. The interplay of these factors affects the political economy of migration: public perceptions of migration and policies chosen by the governments often depend on which groups gain more, less, or possibly lose from migration and on their relative political weight.

This section will discuss the existing evidence about the channels through which immigration affects the labor market, economic growth, public finances, incidence of crime, and inequality in the destination country and the characteristics, both of immigrants and of the receiving economies, that affect such impacts. Two important factors affecting those outcomes are the type of migrants moving to a destination country and their speed and degree of integration in the local economy and the formal labor market. Immigration inflows, including a large number of highly skilled and working immigrants, will have a particularly beneficial impact on the economic and employment growth of the receiving country and on its public finances.

We start by considering a few statistics to illustrate the reality of immigration. From the viewpoint of destination countries, migration flows tend to be a highly concentrated phenomenon, in the sense that the top destinations for migrants account for a large share of them. Figure 3 from World Bank (2019) shows the largest destinations of international migrants in absolute numbers and as a proportion of the resident population. Countries in Europe, North America, and the Persian Gulf region as the largest recipients of international migrants. The main reason for this concentration of migrants is the tendency to move to economically successful countries and to the dense and fast-growing urban areas within those countries. The top 10 destination countries account for 60 percent of global immigration (World Bank, 2018). Within the US, two-thirds of arrivals settle in 6 states, within them in only a handful of counties. Cities like New York, Los Angeles, London, and Vancouver have become important migration hubs, with a share of foreign-born in their population significantly larger than in the rest of the country, sometimes as large as 40 or 50 percent of their residents. 
Figure 3. Top 20 destination economies by number of international migrants and refugees and by share of the population, 2018
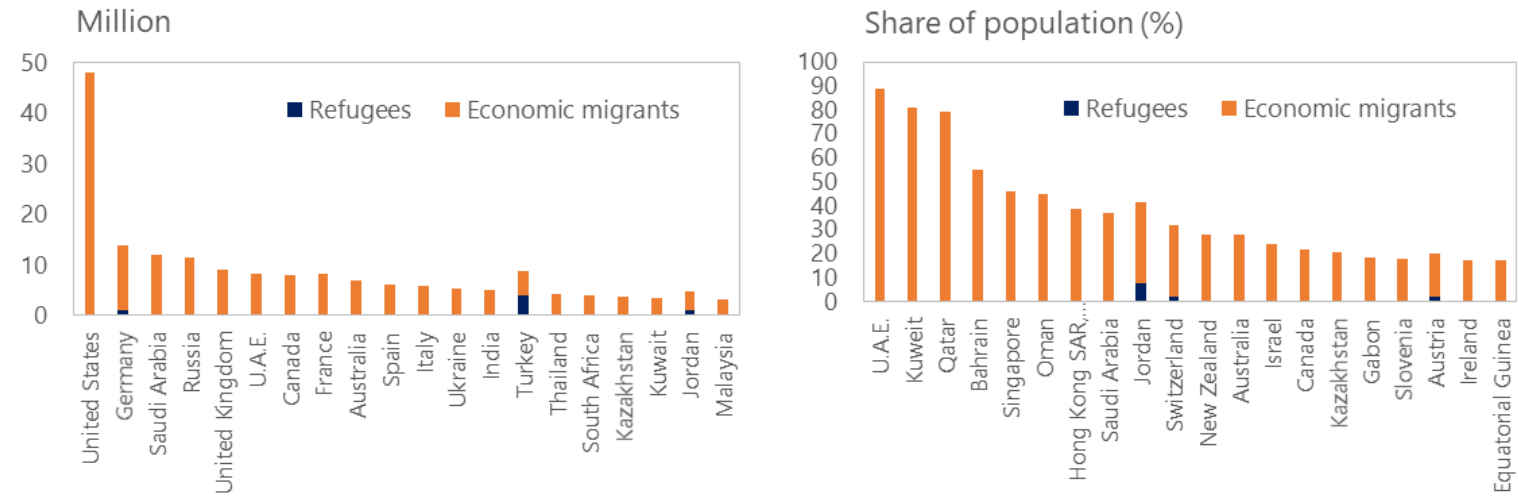

Source: World Bank(2019) based on UNDESA(2017)andUNHCR

\section{A. Impact on the Labor Market}

While the flow of migrants, especially from developing to advanced economies, tends to follow economic success, the question is whether migrants themselves contribute to the success of the receiving economy or whether their presence deprives natives of job opportunities and/or it represents a burden to citizens. A simplistic model of labor demand and supply, as the one shown in Diagram 1a, would suggest that immigration, represented as a simple shift in labor supply, with a downward-sloping labor demand curve and keeping everything else equal, would reduce wages of natives or crowd out their employment if wages are rigid. Some studies, such as Borjas (2003), have argued that this "wage depressing effect" is significant and not negligible.

\section{Diagram 1. Wage effect of migration}
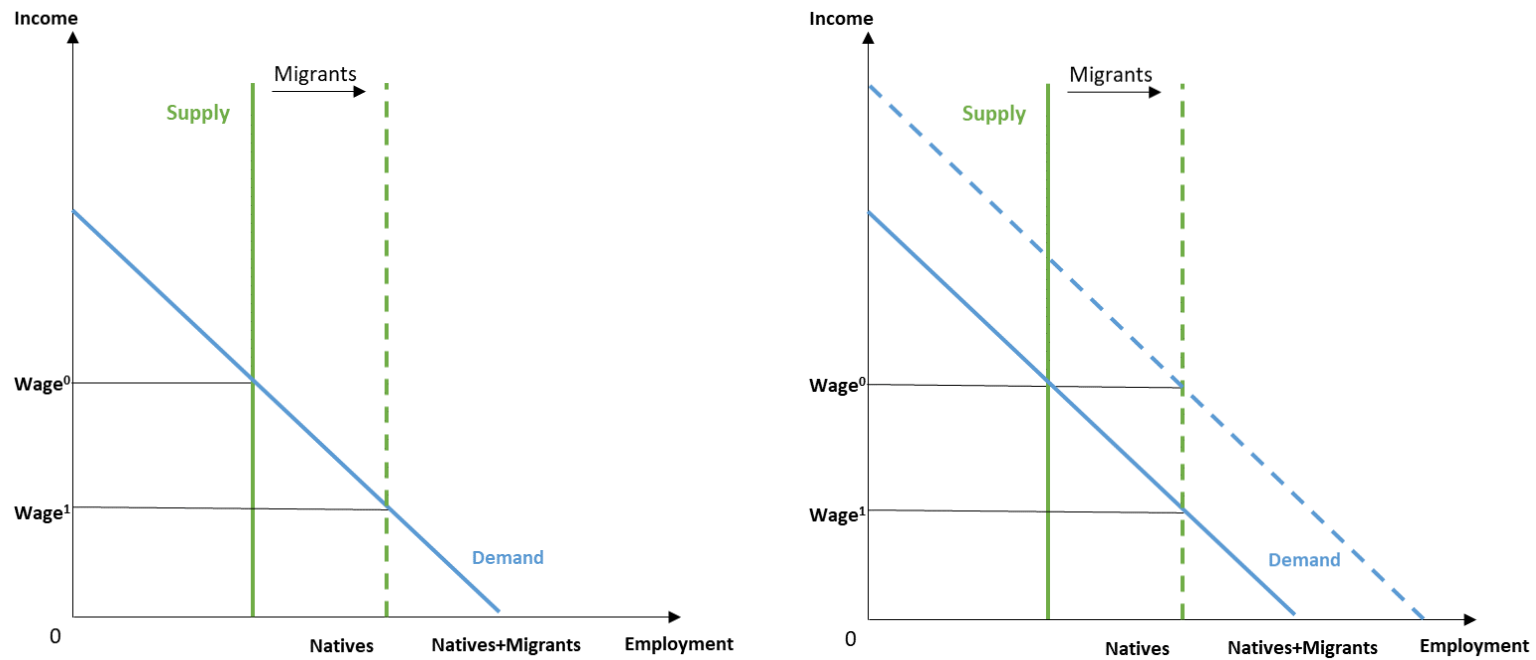

Source: Authors 
Several considerations and extensive empirical evidence, however, suggest that the inflow of immigrants may affect the receiving economy through other channels, which would shift the labor demand curve to the right, and as a result, produce an overall impact on wages and employment of natives that could be null or even positive (as represented in Diagram 1b). Abundant empirical evidence, especially in recent years, suggests that those channels are important.

First, immigrants often take jobs that are different and complementary to (rather than in competition with) those of natives (Peri and Sparber, 2009). Second, they increase local demand as they consume and invest, and this can, in turn, increase labor demand to produce local goods and services (Peri, Rury, and Wiltshire, 2020). Third, firms often respond quickly to immigration by both expanding and moving to where new immigrants arrive, generating investments and more opportunities for natives (Beerli et al., 2018). Fourth, many immigrants are entrepreneurs themselves, and they create firms and opportunities for natives (Lofstrom and Fairlie, 2015). Vandor and Franke (2016) report that immigrants represent 27.5 percent of the country's entrepreneurs but only around 13 percent of the population in the United States. Similarly, about a quarter of all technology and engineering companies started in the US between 2006 and 2012 had at least one immigrant co-founder. Finally, in the longer run, the variety of skills and ideas of immigrants is highly correlated with innovation and growth (Kerr and Lincoln, 2010; Docquier et al., 2018).

The combination of these effects implies that it is important to analyze the relation between immigration and wages empirically. In a review of literature, Peri (2014) concludes that the effects of immigrants on average native wages are close to zero. Based on 27 empirical studies corresponding to more than 270 baseline estimates, the estimated elasticities range from -0.8 to 0.8 , with about 80 percent of the studies showing an elasticity of local wages to immigration concentrated between -0.1 and 0.2 . Such a large sample of elasticity estimates around zero is consistent with the idea that the negative competition-crowding out effects are balanced by positive demand/complementarity/productivity effects of immigrants that we will discuss below.

These studies vary in terms of countries considered, a unit of analysis (local areas, states, or countries), and in an identification strategy. Typically, most of them use local area-level variation in immigrants' inflows and in wages and adopt an instrumental variable strategy to address endogeneity issues. The fact that migrants tend to go to locations where wages are growing can bias the OLS estimates. Using historical enclaves of country-specific immigrants as a predictor of where new immigrants locate, in a shift-share instrumental variable, usually reduces such endogeneity bias.

Besides analyzing cross-sectional and panel evidence on the impact of immigrants on wages, many economists have also studied specific events to try to isolate the short-run effect of immigration and possibly find the negative wage impact suggested by the simple labor supply shift, all else equal. Considering sudden, push-driven, and "quasi-experimental" events can also alleviate the problem of endogeneity. In those events, migrants were not attracted by economic conditions but were fleeing events in the place of origin; hence there is no reason to think that their sudden arrival was correlated with local wage growth. 
One of the first and extensively studied natural experiments was the Mariel Boatlift ${ }^{3}$. In April 1980, Fidel Castro opened the port of Mariel in Cuba to enable anyone who wanted to emigrate to do so. Between April and September of that year, 125,000 Cuban refugees arrived on the coast of Florida in the US, and many of them settled in Miami, where there was already a large Cuban community. The labor supply in this metropolitan area increased by about 8 percent, and this increase was concentrated among less-skilled workers, as most migrants had low levels of schooling. This event provides an opportunity to identify the short-run impact of a large, exogenous, and sudden influx of low-skilled migrants, as researchers can compare the labor market conditions in Miami versus other American cities that did not experience a similar arrival of migrants. The sudden occurrence and exogeneity of the event provide good identification.

Despite the sudden nature and large inflow of immigrants in Miami, this case does not provide clear evidence of a negative effect of immigrants on wages. While a study by Borjas (2017) finds that wages decreased significantly for the group of non-Hispanic native workers with no high school degree, Card (1990) and Peri and Yasenov (2017) find that the event left the wages and employment of most native groups unaffected, and only when considering very small groups, whose wages are likely to have large measurement error in the Current Population Survey (CPS) sample, one can find some negative (imprecisely estimated) effects. The estimated effects on most groups for which there are enough observations are very small and often non-negative. The following sections will detail the different potential channels through which immigration may affect native wages.

\section{The substitution/complementarity effect}

The effect emphasized by Borjas (2017) when analyzing the Mariel Boatlift and in most of his other studies of immigration (for instance, Borjas, 2003; and Borjas, 2014) is the competition (substitution) effect of immigrants, especially for natives with less than a high school degree. Such effect can be represented as adding more identical workers to the supply of less-educated natives and as a shift of the supply curve to the right, illustrated in Diagram 1a above. This effect, by itself, would result in downward pressure on wages for less-skilled natives.

Such an effect assumes, however, that immigrants and natives supply the same type of labor, i.e., are substitutes, and that nothing else changes in the local economy, specifically that firms do not adjust their physical capital. Several recent studies have pointed out that immigrants, because of their different specialization, skills, and language ability, are not substitutes of natives, even for similar levels of schooling (Peri and Sparber, 2009; Card, 2009; Cattaneo, Fiorio and Peri, 2014; D'Amuri and Peri, 2014). If immigrant labor is a different type of labor relative to natives', then the increase in its supply may increase the marginal productivity of native labor and shift its demand to the right. Moreover, firms and

\footnotetext{
${ }^{3}$ Some other natural ex periments studied in the litera ture include the return of French expatriates to their home country after Algeria declared its independence in 1962 (Hunt, 1992); the repatriation of Portuguese from Angola and Mozambique in the 1970s following their independence (Carrington and De Lima, 1996); ethnic Germans living in Eastern Europe and in the former Soviet Union returning to Germany after the fall of the Berlin Wa ll in 1989 (Glitz, 2012); the flow of refugees from Burundi and Rwanda to Tanzania following the civil war and genocide in those countries (Maystadt and Verwimp, 2014); and the large wave of migration from Central American countries to the US following Hurrican Mitch in 1998 (Kugler and Yuksel, 2008).
} 
investment seem to respond relatively quickly to the opportunities created in a local economy by new workers (Olney, 2013), so that physical capital increases and the short-run labor demand curve may shift to the right, as illustrated in diagram $1 \mathrm{~b}$ above.

One group that may feel the competition of new immigrants more than natives are previous immigrants. Some studies (e.g., D’Amuri, Ottaviano, and Peri, 2009) find a sizeable competition effect on previous immigrants: ten new immigrants in the Western German labor market drive three to four old immigrants out of employment while having no effect on natives. The high degree of substitutability between new and previous migrants (Beine et al., 2011), the tendency of new migrants to cluster in areas in which previous migrants are already over-represented (World Bank, 2018), and wage rigidity contribute to this effect.

\section{The productivity and demand effect}

One reason that makes the Mariel Boatlift episode rather dated and not very representative of the impact of immigration is that those migrants were mainly uneducated. In the last 20 years, in most OECD countries (Docquier, Ozden, and Peri, 2014), including the US, immigrants, on average, were more skilled than natives. In this case, immigration would result in an increase in the relative abundance of skilled people with further positive complementarity effects on less educated and, potentially, with important productivity effects. This type of immigration would increase the relative wages of low-skilled workers and potentially also reduce inequality in the long run. Moreover, if high-skilled immigrants have a positive effect on innovation and productivity (e.g., Kerr and Lincoln, 2010; Peri, 2012 ) in the long run, this will help economic growth and wage growth for the whole economy.

Another channel through which immigration may increase native employment is through providing services that increase native labor supply. Tessada and Cortes (2011) and Jaumotte, Koloskova, and Saxena (2016) find that the availability of relatively low-cost workers in the services or health care sector may allow high-skilled women to join the labor force or work longer hours, increasing the country's productivity. Highly skilled native women can join the labor market because they can employ lower-skilled immigrants. Conde Ruiz, Ramón Garcia, and Navarro (2008) find that the rapid increase in immigration in the early 2000s in Spain led to growth in the personal services sector, which in turn had a positive impact on female labor force participation.

Furthermore, immigration, by covering some specific manual, labor-intensive jobs, encourages high-skilled native workers to specialize in more complex occupations, thus raising their productivity and wages through "occupational upgrading" (Cattaneo, Fiorio, and Peri 2014; Foged and Peri 2016). If migrants fill sectoral labor shortages, then immigration might have a positive effect on native workers.

Immigration also has a demand (or scale) effect. Immigrants demand goods and services, and their presence leads to an increase in overall production. The scale effect of immigration generates an increase in employment among native workers due to the rise in output (Ozden and Wagner, 2014). Bodvarsson and Van den Berg's (2006) study of a flow of Hispanic immigrants to a meatpacking plant in Dawson County in Nebraska shows that immigration can substantially boost local consumer demand. Bodvarsson et al. (2008) find strong 
evidence that immigrants increased consumption and demand for local services in Miami after the Mariel Boatlift event.

The demand and productivity effects aggregate to generate the shift of the labor demand line to the right, as shown in Diagram 1b. The shift in demand can be smaller, as large, or larger than the shift in supply, generating a net decrease, no change, or increase in natives' wages. The shifts of demand and supply in Diagram $1 \mathrm{~b}$, generating roughly no wage change, correspond to what most studies find as the effect of immigration on average and low-skilled native wages.

Finally, studies show that migrant networks foster trade and FDI (Cohen, Gurun, and Malloy, 2017; Parsons and Vezina, 2016; Burchardi, Chaney, and Hassan, 2016), contributing to economic growth. For instance, Javorcik et al. (2011) find that US FDI abroad is positively correlated with the presence of migrants from the host country. While this is likely to have a beneficial impact primarily on the country of origin, it can benefit the destination country as well. Immigrants lower informational barriers through the knowledge of their home country's language, regulations, market opportunities, and informal institutions.

In summary, one can understand the overall impact of immigration on native workers' wages and employment only by combining the substitution, complementarity, productivity, and demand effects. Most studies find close to zero overall effects on average wages, suggesting that the negative substitution effect is offset by the positive effects on native wages. The impact on wages of low-skilled, high-skilled, and wage inequality also depends on the skill composition of immigrants and the response to it. Most studies do not find much effect on native wage inequality from immigration, suggesting that the other factors compensate for the pure substitution effect.

\section{B. Impact on Public Finance}

Another significant concern in the public opinion toward immigrants is their impact on public finances, specifically whether they are net contributors or net recipients of welfare transfers. Dustmann and Preston (2007) show that this concern is even more salient in people's minds than the impact of migration on wages and employment. The perception that immigrants pose a burden on public finances may explain why, in many developed countries, wealthier individuals are often in favor of restricting migration, despite the fact that the owners of capital are likely to gain from the inflow of labor.

In the short term, migrants tend to impose a cost on the destination country, especially in the area of social integration and assistance and as they may take some time to find a job. These costs are higher for refugees and lower for economic immigrants. In terms of health care, immigrants tend to be less costly than natives for a long time, as they tend to move when they are young. Over time, migrants have a net positive effect on government budgets if they successfully integrate into the labor market. In aging societies, the immigration of young workers could ease the fiscal sustainability pressure of pension systems as well as help paying the medical costs of retirees. 


\section{Short-term fiscal impact}

The short-term fiscal costs of immigrants are likely to be mainly for social assistance, labor market integration, unemployment benefits, as well as administrative costs. These costs depend on the generosity and the coverage of the social protection system in the receiving country, as well as on the type and skills of immigrants. As a consequence, the calculation of the fiscal costs of immigrants can be quite country-specific. In addition to these differences, in some countries, asylum seekers receive accommodation, subsistence, and integration support (such as language classes), and these add to the fiscal cost. As refugees account for only around 10 percent of migrants to OECD countries, these costs are small for most advanced economies. In the case of a country like the US, where immigrants work at high rates, and there is a balance between high and low skilled, Flavin et al. (2011) estimate that the fiscal cost per capita of foreign-born is between half to two-thirds that of US-born individuals.

A different picture would emerge if we focus on the countries (mainly developing) shouldering the costs of significant flows of refugees. These flows can be unexpected, affect most countries near the origin of refugees, and may imply a high short-term cost, including the setting up of refugee camps. For instance, the recent refugee wave from Syria in 2012-15 has brought millions of refugees, especially to the neighboring countries of Jordan, Lebanon, and Turkey (in the case of Jordan, the inflow was equivalent to about 10 percent of the population). The estimated fiscal cost of these refugees was 2.4 percent of GDP for Jordan, 3.2 percent for Lebanon, and 1.3 percent for Turkey (Rothers et al., 2016). In 2018, the estimated fiscal costs associated with migration flowed from Venezuela were 0.5 percent of the GDP of neighboring countries.

So, in the case of fiscal impact in the short-run, it is crucial to distinguish between economic migrants, mostly moving to advanced economies, who have small initial costs and are distributed over a longer time period, and refugees, mostly moving to neighbor developing countries, which may represent a significant short-run fiscal transfer.

\section{Long-term fiscal impact}

Over time, migrants contribute to the destination country's revenues by paying taxes. The long-term fiscal impact of immigration depends on the generosity, design, and coverage of the tax and benefit system. To estimate the long-term fiscal impact of immigrants in destination countries, we need to evaluate the following equation:

\section{Diagram 2. The net fiscal impact of immigrants}

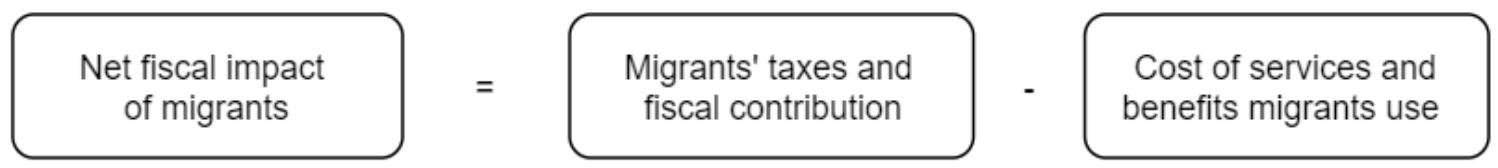

Integration into the formal labor market is the key to generating a positive long-term fiscal impact. Migrants' skill composition is also important: higher-skilled migrants are expected to contribute more to the tax system because of their higher income. Dustmann and Frattini (2014) show that migrants who arrived in the United Kingdom after 2000 were on average 
highly skilled and had a higher positive net fiscal contribution than did the native population. Similarly, Orrenus (2017) show a positive net fiscal contribution of immigrants in the US over their lifetime, especially for more recent migrants.

Another important component in assessing the fiscal impact of immigrants is the demographic structure of the native and immigrant population. In countries with an aging native population, like in most advanced economies, immigrants (who are usually young) increase the size of the labor force and reduce the old-age dependency ratio, i.e., the number of retired people relative to those of working age. This demographic effect helps reduce the adverse fiscal impact of an aging population. Pension and healthcare spending in developed economies is projected to reach 24.8 percent of GDP by 2100 , up from 16.4 percent in 2015 simply because of population aging. Clements et al. (2015) show that allowing for more immigration could help reduce old-age dependency ratios and thus age-related expenditures by 2 percent of GDP by 2100 . Immigration flows will have to increase substantially to fully address the effects of population aging. Nevertheless, moderate inflows of immigrants can alleviate the burden on the pension system, preventing drastic cuts in benefits.

As for native workers, immigrants tend to have a negative net fiscal balance during youth and old age and a positive fiscal balance during their working age. As immigrants arrive in the destination country early in their working age, they tend to have a higher net positive fiscal impact. The receiving countries save the cost of their education and benefit from the many contributing years before retirement.

The OECD (2013) presents an overall picture of the net fiscal impact of immigrants in a cross-country study based on a static accounting model. The impact of immigration on public finances is calculated to be typically \pm 0.5 percent of GDP for advanced economies. In the cases in which immigrants compare less favorably to the native-born population in terms of net fiscal balance, this is mainly due to lower tax contributions rather than greater demand for benefits. This emphasizes the crucial role of immigrants' formal employment rate in determining their economic and fiscal contribution.

\section{Impact on the incidence of crime}

Another major public concern about the impact of migration on receiving countries is the connection between immigration and crime. Statistically, cities with high rates of crime tend to have more immigrants. However, controlling for the demographic characteristics of the cities or using instrumental variables, immigration appears to have little to no significant causal effect on crime rates. Earlier work by Butcher and Piehl $(1998,2007)$ finds no effect of immigration on crime rates in the United States. Youth born abroad are significantly less likely than native-born youth to be criminally active and are also less likely to be incarcerated. Using the immigration status of those who are arrested, Miles and Cox (2014) find similar results. Buonanno and Pinotti (2012) find that only the incidence of robberies in Italy has increased due to immigration, but since robberies represent a small fraction of total criminal offenses, the effect on the overall crime rate is not significantly different from zero.

Labor market opportunities are a key determinant of the criminal behavior of individuals, including immigrants. In the Becker-Ehrlich model of crime (Becker 1968; Ehrilich 1973), individuals rationally choose between crime and legal labor market work depending on the potential returns of each option. The "return" from crime is weighted by the probability of 
getting caught and sanctioned and compared to the earnings from formal employment. If the former outweighs the latter, an individual will engage in crime. Translated into the context of migration, the model suggests that integration into formal employment reduces the probability that migrants commit crimes. Bell, Fasani, and Machin (2013) compare two large waves of immigration in the UK (the late 1990s/early 2000s asylum seekers and the post2004 inflow from EU accession countries), and find that only immigrants in the former group caused a modest but significant increase, and only in property crime. The former group was also characterized by limited access to the official labor market.

Both in the United States and in Europe, undocumented immigrants cannot officially work or start a new economic activity. In the United States, nevertheless, undocumented immigrants have been shown to have very high employment rates in the legal economy, presumably due to lax enforcement and a nearly zero labor supply elasticity (Borjas, 2016). When immigrants can only participate in the informal economy, they face inferior earnings opportunities relative to their legal counterparts (Kossoudji and Cobb-Clark, 2002; Lozano and Sørensen, 2011). In line with the findings that migrants with a formal job tend to commit less crime, legal immigrants also have much lower crime rates than illegal immigrants (Mastrobuoni and Pinotti, 2010). Pinotti (2017) shows that legalization reduces the crime rate of immigrants by 0.6 percentage points on average, on a baseline crime rate of 1.1 percent in Italy.

\section{Adopting reasonable immigration policies and fostering integration}

Given our description of the potential economic, labor market, and fiscal benefits from immigration with some evidence of potential short-term costs on native-born, we now discuss some policies that may help ease the initial cost and enhance and redistribute the economic benefits of migration so that policies chosen by the government are supported by the citizens.

Immigration policies based on forward-looking considerations, such as the country's population projection and expectation of labor force needs, are more likely to succeed.

\section{Reaping the benefits of immigration}

When looking at policies in countries with large numbers of immigrants, those based on selecting immigrants for their skills, such as Canada and Australia, seem to have succeeded in selecting a large number of immigrants with skills in line with the economic needs of the countries. Those more centered on family ties and reunification, such as the US, have often produced bottlenecks (oversubscription of the H-1B) or generated other, less efficient channels of the entry (undocumented inflows). Also, the level of public support for immigration has remained higher in Canada than in the US.

Integrating migrants into the labor market is a key to achieving their full productive contribution and to limiting their potential burden on public finances. This suggests that an immigration system centered around working visas and permits is more likely to be economically successful for the immigrants and for the receiving country. At the same time, reducing the opportunities to access formal work, as done in some cases for asylum seekers, leads to a loss of tax revenue, a likely deterioration of their human capital, and, in the long run, to higher welfare benefit bills. 
While it is not easy to find policies that are effective in integrating refugees and noneconomic migrants into the domestic labor market, there is evidence that some basic education, including basic health care and especially language training (see Arendt et al., 2020) could be effective in increasing their long-run employment and earnings potential. Extremely important is the schooling of the second generation. Children of immigrants have the opportunity of full integration if given the right schooling opportunities. On the other hand, Helbling, Simon, and Schmid (2020) show on the evidence of 22 European countries that immigration restrictions do not lead to better integration of migrants.

In helping their chances in the labor market, governments should provide timely work permit authorizations and a swift process for certificate, degree, and license recognition across countries in order to tap into the full potential of migration. According to OECD (2018), the average overqualification rate of the foreign-born population in the EU was over 33 percent, compared to 21 percent for native-born workers (over-qualification is defined as the share of tertiary-educated employees who work in a job that is ISCO-classified as low or mediumskilled, i.e. ISCO levels 4 to 9). Employment rates for migrants are higher in countries with low entry-level wages and less employment protection (Ho and Shirono, 2015). Encouraging migrant entrepreneurship could help foster competitiveness and innovation and create positive spillovers. Securing access to financial services, such as bank accounts and financial transactions, can also broaden their opportunities.

Once migrants have a job, it is important to provide a clear path to residency and employment security. Uncertainty leads to inefficiency and long-term cost for both migrants and their employers (World Bank 2018). This is particularly important for highly skilled workers, as firms tend to invest more in their positions. A system in which a temporary visa can be converted to a permanent one if employers are willing to sponsor the immigrants, as it is for H1-B visas in the US, may offer the flexibility and the certainty needed.

\section{Minimizing the impact on native workers}

A large body of research finds that natives will respond to immigration by upgrading and adjusting their occupation and job (Peri and Sparber 2009; Cattaneo, Fiorio and Peri 2015). Policies to help native workers during their adjustment and relocation may further help reduce the costs and increase the benefits from immigration. Adjustment assistance mechanisms target native workers who compete with migrants to provide them with more relevant skills. Relocation assistance can include assistance with changing occupations, cities, or sectors of employment. This can also include transitory welfare benefits or unemployment insurance payments. However, both mechanisms require that authorities identify the impacted native population, which is very difficult. It may be best just to promote efficient and flexible labor markets, where the cost of changing jobs is small, and workers can transition easily across occupations. By moving to complex jobs, natives protected their wages from the immigrant competition and took advantage of the creation of those jobs that complement the manual tasks provided by immigrants. Letting this mechanism work may benefit less-educated natives, in particular through more hiring in those occupations. Strong protection of labor hurts this mechanism and reduces labor markets' ability to absorb immigrants through the occupational upgrading of natives (D'Amuri and Peri, 2014). If there is a concern of competition effects on a group of vulnerable native workers, such as low educated manual workers, Minimum income schemes, 
as in Denmark, or minimum wage could be alternatives, but more research is needed to fully understand their implications.

In this context, encouraging immigration fees rather than quotas can be a sensible approach to the issue. To finance adjustment or relocation, policymakers could impose a fee on employers hiring foreign workers so that those who are getting the surplus from such hires are also responsible for paying some of the costs. Both Singapore and Malaysia have such a scheme in place, but to our best knowledge, no compelling assessment of its efficiency has been conducted. Immigration quotas, especially when the cap is determined by the bureaucratic assessment, rather than by employers and the market, lead to misallocation, increase the risk of rent-seeking and corruption (by government officials), and do not generate any revenue. Instead, a visa fee or a visa auction system has the advantage of letting firms choose the workers while providing extra revenue to the government that could be used to alleviate transitional costs.

\section{Paying special attention to refugees}

While most economic migration flows are gradual enough for destination economies to plan and absorb, the case can be different for refugees. Sometimes, a large number of people move over a short period of time to countries with limited resources. Policies that are related to hosting refugees introduce different challenges and require additional attention. The reasons to admit them are humanitarian rather than economic. However, especially if accompanied by the right policies, refugees can turn into a valuable economic asset for the receiving country in the medium and long run.

First, as mentioned above, asylum seekers should be allowed to work early on in the process of requesting asylum. Given their likely trauma and skill deterioration due to the circumstances that caused their migration, they may be in particular need of policies to improve skills and language before accessing the labor market. Encouraging refugees to move to places with labor demand for their skills can ease integration. Introducing temporary wage subsidies can create incentives for employers and improve migrants' integration.

Monitoring countries that are becoming unstable and offering their citizens an option of orderly migration for labor purposes before a crisis erupts can be an important mitigation mechanism. A solution, when a migration crisis is underway, could be to spread the burden of refugees across countries. Compared to the population of advanced countries or to economic migrants, the number of refugees remains small. World Bank (2018) suggests establishing an active large-scale refugee settlement policy and coordinating financial assistance. 


\section{IMPACT OF MIGRATION ON ORIGIN COUNTRIES}

On a global scale, emigration is more dispersed between countries than immigration. In most countries, the share of emigrants relative to the countries' total population does not exceed 10 percent. Notable exceptions include some fragile states and also clusters of countries with high emigration in Eastern Europe, Central Asia, and Latin America.

In some regions, in particular Europe, Central Asia, and SubSaharan Africa, a large part of emigration (70-80 percent of the migrants) goes to countries in the same region (Figure 4, from World Bank, 2019). The share of emigrants moving intra-regionally is much lower in Asia and the Americas.

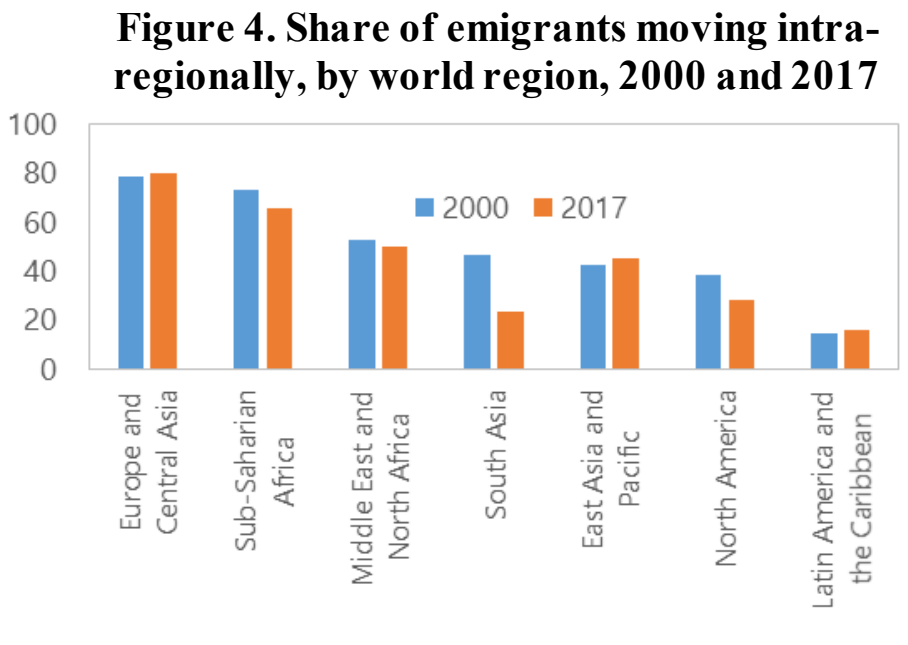

Source: World Bank(2018) based on UNDESA 2017

\section{A. Impact on the labor market in origin countries}

On the theoretical level, the impact on the labor markets in the origin countries can be seen as a mirror image of the impact in destination countries. An outflow of labor can be expected to reduce the supply of the workforce but also reduce demand, human capital, and entrepreneurship with ambiguous overall effects on wages. In countries that are suffering from chronic unemployment (or underemployment), emigration can ease tensions in the labor market and improve the availability of jobs, as long as the demand and human capital effects do not depress local labor demand. As emigrants are usually positively selected in terms of skills (Grogger and Hanson 2011), their loss can contribute to a loss of productivity, ability to innovate, and net loss in fiscal balance. Furthermore, symmetric to the case of destination countries, emigration can create negative demand and productivity effects.

Perhaps not surprisingly, empirical evidence on the labor market impact in origin countries is somewhat contradictory. Dustmann et al. (2015) argued that large-scale emigration did, in fact, raise employment and wages in Poland following its entry into the European Union. At the same time, IMF (2016, SDN/16/07) noted that, as emigrants are primarily high-skilled workers, emigration creates a negative externality, which leads to a reduction in productivity. This can also lead to other negative consequences, which are described in more detail later, in the section on brain drain. 


\section{B. The role of remittances}

Remittances are perhaps the most highly visible and tangible benefit of emigration to the origin countries. On a global level, the World Bank estimates officially recorded remittances at $\$ 548$ billion in 2019 , more than three times the volume of official development assistance and comparable in size to total FDI flows. Not surprisingly, remittances have become a major source of inflows in many countries. They are often in the range of 15-20 percent of GDP, and in some exceptional cases, can reach 30-40 percent of GDP (Tonga, Haiti, Kyrgyz Republic).

These large volumes are transferred, even though sending money across borders remains expensive, with fees often surpassing 5 percent. Costs vary widely across corridors and providers. They tend to be highest in small markets with little competition and through commercial banks. Recent advances in mobile technology will likely help bring remittance costs down (Cecchetti and Schoenholtz 2018, Schmitz and Endo 2011).

In many countries in Asia and Africa, remittances have helped to significantly reduce poverty levels and improve nutritional and educational outcomes, in particular by reducing the need to send children to work (Binci and Giannelli, 2018; Bargain and Boutin 2014).

Remittances can also foster consumption smoothing, not only through their own countercyclicality but also by supporting financial inclusion and access to credit. Remittances allow recipients to save in good times and tap into these resources in periods of falling domestic income. They facilitate access to credit by endowing borrowers with collateral and strengthening their capacity to repay. These effects are likely to be especially important for liquidity constrained, poorer households.

There is an emerging consensus in the literature that migration and remittances are part of an overall livelihood strategy through which households try to cope with shocks. For instance, contrary to private international capital flows, remittance flows do not depend on interest rate differentials. They remain stable or even increase after the onset of natural disasters (World Bank, 2006). Increased remittances helped smooth household consumption and compensated for the loss of assets after earthquakes (Halliday 2006; Suleri and Savage 2006), tsunamis and cyclones (Fagen 2006; Wu 2006), floods and droughts (Arouri et al., 2015; Davies, 2008; Mohapatra et al., 2009). Their role as insurance has also been documented in relation to shocks to the individual income (De Brauw et al., 2013) or health (Ambrosius and Cuecuecha, 2013).

There is also some evidence that migrants transfer funds to their countries of origin at times of conflict when other flows have all but disappeared. Weiss, Fagen, and Bump (2005) document the increasing role of migration and remittances during crises in Afghanistan, Somalia, and Eritrea. Koczan (2016) shows that remittances from Germany to ex-Yugoslavia increased during the conflict of the early 1990s, despite the breakdown of formal intermediation channels.

The impact of remittances on various macroeconomic outcomes in the countries of origin is far from simple. Abdih et al. (2012a) show that (unsurprisingly) remittances improve fiscal balance by increasing the aggregate private demand and thus expanding the tax base, 
especially for VAT and sales taxes. This, in principle, provides additional revenue for the government to pay for social spending that benefits the poor. However, the expansion of private demand happens mainly through increased consumption. To the extent that remittances are not consumed, they are saved in the form of assets such as gold and real estate and do not typically increase private investment.

Remittances can also have other negative effects that can hurt development in the countries of origin in the long term. Abdih et al. (2012b) argue that remittances negatively affect governance by creating a moral hazard problem. Remittances ensure the households against adverse economic shocks and insulate them from government policies, and thus reduce the incentives to pressure the government to implement necessary reforms to facilitate economic growth. In turn, this reduces incentives for the governments to implement reforms and can erode fiscal and debt discipline. Moreover, by providing large substitute income for families, remittances can reduce labor force participation rates, especially for women.

The impact of remittances on inequality will generally depend on which hou seholds receive them and how much they receive. As long as families who are on the receiving end of remittance transfers are disadvantaged and low-income, remittances have the potential to lower inequality. Beyond their direct effects on income, remittances could also affect inequality through their indirect macroeconomic effects, insofar as they facilitate setting up businesses, resulting in employment creation which tends to be pro-poor.

Most early studies examined the distributional effects of remittances by comparing income distributions with and without remittances (simply subtracting remittance amounts from income for remittance-receiving households) or by using income-source decompositions of inequality, computing Gini coefficients separately for non-remittance income and remittance income (Adams and Alderman, 1992; Stark et al. 1988, and Taylor et al., 2009). This approach implicitly assumes that there would be no behavioral changes in the absence of remittances. It would, however, seem likely that, given the drop in income, other household members would start working or increase their working hours. To take this into account, several recent studies have created counterfactual income distributions, designed to capture what a migrant's income would be in the home country in the absence of migration, as well as what the participation decisions and earnings of other household members would be.

Although they rely on similar methodologies, these studies nonetheless reach different conclusions. Möllers and Meyer (2014) find that remittances increase inequality in Kosovo, while Mughal and Anwar (2012) and Koczan and Loyola (2018) find that they lower it in Pakistan and Mexico respectively.

These conflicting findings may be driven by differences in the "migration stage" of a country. As highlighted by Stark et al. (1988) and Taylor et al. (2009), "pioneer" migrants who lack pre-existing migrant networks and therefore face higher costs of migration may come from wealthier households. In contrast, later migrants, who come from poorer households, may benefit from falling costs as migrant networks expand. If so, migration and associated remittance receipts will first increase then reduce inequality in sending countries.

This interpretation is consistent with the findings of Acosta et al. (2008), who identify different effects across Latin American countries depending on their migration histories, the 
extent of migrant networks, and proximity to migrant destinations. Migrants and remittancereceiving households are more likely to be from the bottom of the income distribution in Mexico and Paraguay, with longer migration histories and lower costs of migrating to their main migrant destinations, whereas migrants tend to be drawn from higher-income portions of the population in Haiti, Peru, and Nicaragua. Brown and Jimenez (2007) find larger poverty- and inequality-reducing effects of remittances and migration in Tonga, an economy with a relatively long migration history and high remittances, than in Fiji, an economy with a more recent migration history.

Margolis et al. (2013) similarly point to larger inequality-reducing effects in Algerian regions with more migrants and remittance-receiving households. Further consistent with this view, McKenzie and Rapoport (2007) find that migration and remittances reduce inequality in rural Mexican communities with high levels of past migration. Acharyaa and Leon-Gonzalez (2012) argue that remittances from India (unlike remittances from elsewhere) reduce inequality in Nepal due to the greater participation of the poor in the Nepal-India migration process. Möllers and Meyer's (2014) contrasting finding that migration and remittances increase inequality in rural Kosovo similarly could be explained by the country's recent migration history and consequently high costs of migration.

Thus, while the findings of different studies are mixed, their differences may reflect changing effects over time and indicate that any inequality-reducing effects of remittances are more pronounced in countries with longer migration histories, where the fixed costs of migration are lower, and migration and remittances are more accessible to poorer households.

\section{Impact through trade and investment}

Emigration can also help the origin countries through better and easier integration into global trade and investment. Parsons and Vezina (2016) demonstrate that, following the lifting of trade restrictions in 1994, US exports to Vietnam grew most in US states with larger Vietnamese populations, which resulted from large exogenous refugee inflows 20 years earlier. Burchardi, Chaney, and Hassan (2016) show that the impact on investment from the receiving country can be long-lasting. They use 130 years of historical data on migration to the US to show that the ancestry composition of US counties has a causal effect on foreign direct investment sent and received by local firms. Their results show that doubling the number of residents with ancestry from a given foreign country relative to the mean increases the probability that at least one local firm directly invests in that country by four percentage points. This effect appears to be primarily driven by a reduction in information frictions and not by better contract enforcement, taste similarities, or convergence in factor endowments.

The strength of the impact on trade and investment would depend on the skill composition of migrants and on the cohesion and attitude of emigrants. A strong emigrant network that is business-oriented can facilitate trade between destination and origin countries and increase investment flows by leveraging their newly acquired information, business skills, and knowledge of the business and investment environment in the countries of origin. The impact would be further amplified if a country of origin has sound public policies, political stability, a favorable business environment, and low corruption. Trade and investment can also lead to 
easier and cheaper transfers of technology, potentially stimulating convergence and growth of countries of origin.

The investment activity of emigrants can also provide an impulse to the development of capital markets in the countries of origin. These investors can help to diversify the investor base and bring a reliable source of funding into the country. Furthermore, these investors are likely to be able to undertake riskier projects than foreign investors because they can better evaluate the risks and possess contacts and local knowledge that can reduce the risks and that are not available to foreigners.

\section{Costs of emigration associated with the brain drain}

Brain drain, i.e., the emigration of highly skilled and highly productive individuals, is the primary source of concern for origin countries. Data shows that this is, in fact, a valid concern, with the share of highly skilled workers that have left the country reaching 40 percent in some small low-income countries (Artuç et al., 2015) and in general with highly educated being two to three times more likely to migrate than less educated (Grogger and Hanson, 2011).

Brain drain can affect the origin countries in many ways. On the most obvious level, it lowers the human capital of the origin country and produces a shortage of high skilled labor, thereby reducing productivity. This may be accompanied by increases in wages, driven both by the overall shortage of labor and by rising reservation wages due to remittance inflows (IMF, 2016). The combination of these factors can have a significant negative impact on potential growth. IMF (2016) simulates that emigration may have reduced annual growth rates by $0.6-$ 0.9 percentage points in some countries in South-Eastern Europe (Albania, Montenegro, and Romania) and the Baltics (Latvia and Lithuania), also slowing income convergence as a consequence.

Brain drain may also have large implications for public finance. This channel works in particular through shifting tax revenue from income taxes (which decline because of lower high skilled labor) in favor of consumption taxes (which increase because of remittances inflows). Less obviously, it also often shifts the balance of public expenditures, with lower spending on education (which can be explained by lower demand with the outflow of high skilled workers) and higher spending on social assistance programs. The argument on education spending can go the other way; however - Beine, Docquier, and Rapoport (2008) argue that the possibility of migrating increases demands for schooling, generating in net higher skills. On balance, IMF (2016) estimates that emigration during 1990-2012 has been linked to an average increase of overall government spending relative to GDP of 6.2 percentage points in Central European and South-Eastern European countries.

Furthermore, brain drain can have a long-lasting damaging impact on the quality of institutions in the origin countries. Departing high skilled workers are an important potential political force advocating for improvements in business and investment climate and better control of corruption (Omar Mahmoud et al., 2013). With their departure, there is a danger that a country may turn into a passive recipient of remittances, with a large majority uninterested in changing the status quo. 


\section{E. Country Case: Kyrgyz Republic ${ }^{4}$}

The case of the Kyrgyz Republic illustrates many of the points made in this part of the chapter. While the exact number of migrants out of the Kyrgyz Republic is somewhat hard to pin down because of informality and the temporary status of many emigrants, the country has been an important source of migrants in the region for many years. The importance of migration is evident in the size of remittances, which increased spectacularly from virtually zero in 2000, reaching 10 percent of GDP by 2005 and 30 percent of GDP in 2011. Remittances averaged almost 30 percent of GDP during the last decade.

IMF (2016) analyzed the impact of remittances on the Kyrgyz economy and found little evidence of any positive impact on growth, confirming that remittances are typically used for basic consumption and not investment. At the same time, the study found a significant impact of remittances on real effective exchange rate appreciation, suggesting a possibility of Dutch disease-like effects.

During the period of high emigration (beginning around 2000), extreme poverty has been reduced, but overall poverty levels remain high compared to regional peers. Income inequality in the Kyrgyz Republic fluctuated a lot, with civil conflict, political instability, and the banking crisis wiping out the hard-won gains. Nevertheless, inequality has been on a steady declining trend since 2006 (the period that coincided with high emigration), and the Gini coefficient fell by about 10 points during that period.

The outflow of labor did not bring tangible benefits to the labor market. Unemployment remains high, especially among youth and women, and the country lags behind its neighbors in terms of primary school enrolment and youth literacy levels. IMF (2016) emphasized the need to improve the business environment, promote formal employment and build human capital among the key measures to reduce inequality.

\section{F. Country Case: Mexico 5}

Mexico is one of the world's largest recipients of remittances. While in the early years, remittance-receiving households were typically in the middle of the income distribution, there has been a clear shift over time: as the fixed costs of migration fell and migration opportunities became more widespread, remittances became increasingly pro-poor. Remittance-receiving households are on average poorer than non-remittance-receiving households, even when taking remittances into account. Remittances also tend to constitute a larger share of income for poorer households.

\footnotetext{
${ }^{4}$ This section is based on IMF Country Report No. 16/56(Kyrgyz Republic: Selected Issues).

${ }^{5}$ This section draws on Koczan and Loyola (2018).
} 
This pro-poor pattern of remittances is visible in Mexico's Gini coefficient. The Gini coefficient of households'

"no-migration"

counterfactual income is

higher than that of actual

income, suggesting that

inequality would be higher

in the absence of

remittances, even when

taking into account that

remittance-receiving

households adjust their

behavior (Figure 5). The

behavioral response is also

reflected in the

counterfactual inequality

being lower than that based

on income excluding

remittances. This pattern

holds up over time and is especially pronounced in rural areas, which are on average poorer and have more remittance-receiving households.

Remittances also become more pro-poor during economic crises, such as the peso crisis (1994) and the Global Financial Crisis (2008-09). Figure 6 shows that during both crises, the likelihood of receiving remittances as well as their amount as a share of income fell for the

\section{Figure 6. Crisis Effects}

1. Peso crisis

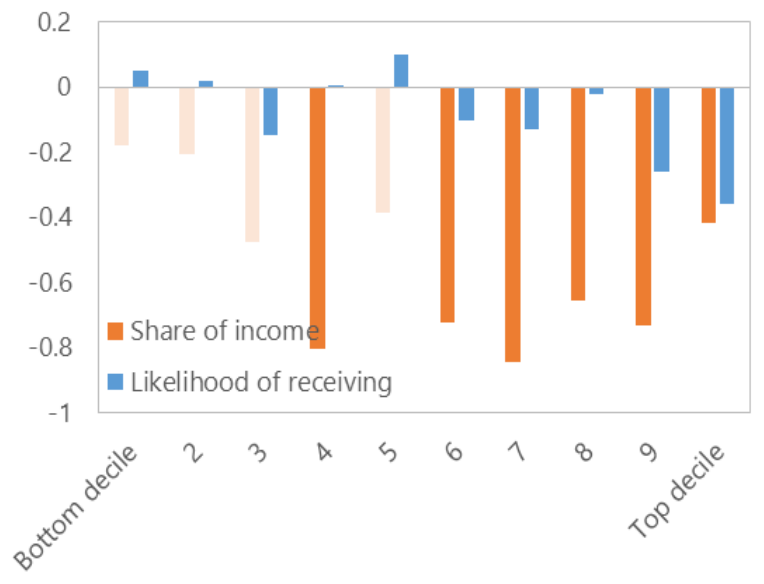

2. Global Financial Crisis

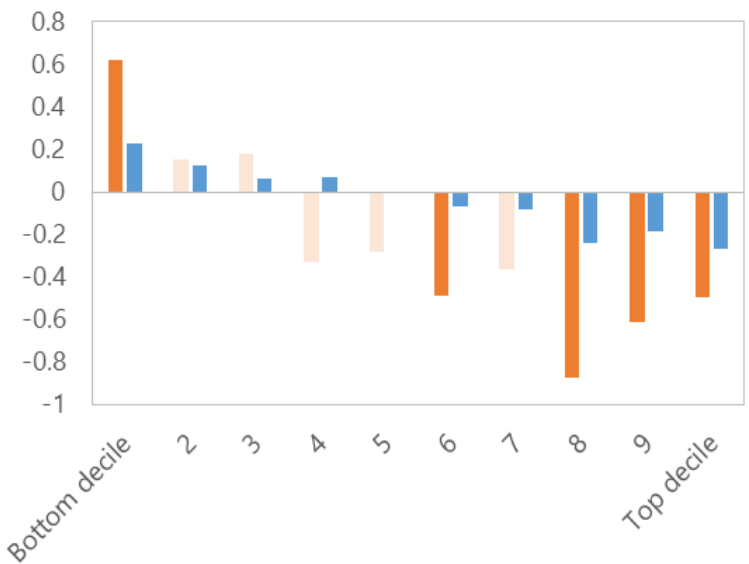

Source: INEGI and Koczan and Loyola (2018).

Note: The figure plots crisis year dummy coefficients. Darker colors denote statistically significant coefficients at the 10 percentlevel. 
top income deciles, consistent with falling investment motives. During the peso crisis, there was little change for the lower-income deciles. However, for poorer households, the likelihood of receiving remittances and their amount as a share of income actually increased during the Global Financial Crisis. This may reflect falling fixed costs of migration, which make migration more accessible to poorer households. Alternatively, this effect could be driven by migrants' better integration in the United States (with higher incomes, more stable jobs, a regularized status), allowing them to better cushion the shock. This insurance effect is quite striking in a context where both the sending and receiving countries were hit by a common shock.

\section{G. Policies that can help the origin countries to maximize the benefits and minimize the costs of emigration}

There are virtually no theoretical or empirical studies that look at potential policies that can be recommended to origin countries or analyze their impact in cases where these policies were implemented. The policies suggested below follow from the discussion of the benefits and costs of migration. Some policies can be aimed at reducing high-skilled emigration and the associated brain drain by addressing the root problems that caused the brain drain in the first place. Others can focus on maximizing the benefits and mitigating the potential negative consequences of outward migration. The former essentially boils down to creating more and better employment opportunities in the origin countries, which can have the triple benefit of slowing emigration, reversing some outflows of labor, and attracting some immigrants from third countries.

- $\quad$ Creating a better business and investment environment can be achieved by improving institutions, maintaining macroeconomic and financial stability, supporting job creation, and improving education. All these measures would strengthen the labor market by creating employment opportunities and thus help to mitigate the negative effect of emigration, as well as to reduce emigration itself.

- $\quad$ Replenishing the stock of high skilled workers is essential for mitigating the negative impact of brain drain. This can be done by encouraging emigrants to return or facilitating high skilled immigration from other countries. Both can be achieved by creating a welcoming environment, easing (re)integration, removing labor market barriers by recognizing degrees from other countries, etc.

- $\quad$ Better utilizing the remaining workforce by increasing labor force participation and improving labor quality through education and on-the-job training would also reduce the costs of emigration.

In addition, given their impact on poverty and inequality, policy measures should aim at maximizing the gains from remittances. Increasing competition among remittance service providers, helping migrants compare costs across different providers, and facilitating mobile technologies can help reduce transaction costs. While remittances may not be very costsensitive, this would nonetheless constitute a welfare gain by increasing amounts received by households. At the same time, policies should help mitigate risks arising from the large dependence on remittances, including by improving investment opportunities, financial inclusion, and access to high-quality, productive jobs in the home countries. 


\section{Conclusion}

Migration is an important phenomenon largely driven by powerful economic and labor market forces: large differentials in wages and employment opportunities, both between advanced and developing countries and within developing regions, create powerful incentives for individuals to migrate in order to achieve a higher income and to increase the expected income for their offspring.

Migration presents both challenges and opportunities for both receiving countries and countries of origin. Policymakers' task is to overcome the challenges and to take advantage of the opportunities. For destination countries, immigrants can create challenges in local labor markets, potentially depressing wages in the short run and displacing some native workers who compete with them. They can also impose short-term fiscal costs and, in some cases, increase the crime rate. But immigrants also tend to boost output, create new opportunities for native workers, provide skills needed for growth, generate new ideas, stimulate international trade and contribute positively to long-term fiscal balances. Integrating migrants into the labor market is key to achieving their full productive contribution, limiting their potential burden on public finances, and reducing their potential impact on crime rates.

For the origin countries, emigration may lead to a loss of much-needed human capital (the so-called brain drain) and create upward pressure on wages, thereby reducing competitiveness. But emigration also creates a flow of remittances, an important source of income for many poor families (albeit their overall macroeconomic impact can be ambiguous). It can also increase international connections in the form of trade, FDI, and technological transfers. For policymakers in countries of origin, the optimal strategy is to improve business and employment opportunities, take advantage of the financial and technological inflows, and reduce the loss of highly skilled labor. 


\section{REFERENCES}

Abdih, Y., R. Chami, J. Dagher, and P. Montiel, 2012b. Remittances and institutions: Are remittances a curse? World Development, vol. 40, 657-666.

Abdih, Yasser, Barajas, Adolfo, Chami, Ralph and Ebeke, Christian, 2012a. Remittances Channel and Fiscal Impact in the Middle East, North Africa, and Central Asia (April 2012). IMF Working Paper No. 12/104.

Abramitzky, R., Boustan, L.P., Jácome, E. and Pérez, S., 2019. Intergenerational Mobility of Immigrants in the US over Two Centuries (No. w26408). National Bureau of Economic Research.

Acharyaa, C.P. and R. Leon-Gonzalez 2012. 'The impact of remittances on poverty and inequality: A micro-simulation study for Nepal.' GRIPS Discussion Paper 11-26.

Acosta, Pablo, Cesar Calderon, Pablo Fajnzylber, and Humberto Lopez. (2008). 'What is the Impact of International Remittances on Poverty and Inequality in Latin America?' World Development 36 (1): 89-114.

Adams, Richard and Harold Alderman (1992). Sources of Inequality in Rural Pakistan: A Decomposition Analysis, Oxford Bulletin of Economics and Statistics 54(4):591-608.

Adams, Richard H., Jr. (2006). 'Remittances and Poverty in Ghana.' World Bank Policy Research Working Paper 3838, World Bank, Washington, DC.

Adams, Richard, Alfredo Cuecuecha, and John Page. (2008). 'The Impact of Remittances on Poverty and Inequality in Ghana.' World Bank Policy Research Working Paper 4732, World Bank, Washington, DC.

Ambrosius, C. and Cuecuecha, A. (2013). 'Are remittances a substitute for credit? Carrying the financial burden of health shocks in national and transnational households,' World Development, 46, pp. 143-152.

Arendt, J.N., 2020. Labor market effects of a work-first policy for refugees. Journal of Population Economics, pp.1-28.

Arouri, M., Nguyen, C. and Youssef, A.B. (2015). 'Natural disasters, household welfare, and resilience: Evidence from rural Vietnam,' World Development, 70, pp. 59-77.

Artuç, E., Docquier, F., Özden, Ç. and Parsons, C., 2014. A global assessment of human capital mobility: the role of non-OECD destinations. The World Bank.

Bargain, O. and Boutin, D., 2014. Remittances and child labor in Africa: evidence from Burkina Faso.

Barrett, A. and Goggin, J., 2010. Returning to the question of a wage premium for returning migrants. National Institute Economic Review, 213(1), pp.R43-R51.

Becker, G.S., 1968. Crime and punishment: An economic approach. In The economic dimensions of crime (pp. 13-68). Palgrave Macmillan, London.

Beerli, A., Ruffner, J., Siegenthaler, M., and Peri, G., 2018. The abolition of immigration restrictions and the performance of firms and workers: evidence from Switzerland (No. w25302). National Bureau of Economic Research. 
Beine, M., Docquier, F. and Oden-Defoort, C., 2011. A panel data analysis of the brain gain. World Development, 39(4), pp.523-532.

Bell, B., Fasani, F. and Machin, S., 2013. Crime and immigration: Evidence from large immigrant waves. Review of Economics and Statistics, 21(3), pp.1278-1290.

Bianchi, M., Buonanno, P. and Pinotti, P., 2012. Do immigrants cause crime?. Journal of the European Economic Association, 10(6),pp.1318-1347.

Binci, M. and Giannelli, G.C., 2018. Internal versus International Migration: Impacts of Remittances on Child Labor and Schooling in Vietnam. International Migration Review, 52(1), pp.43-65.

Bodvarsson, O. and Van den Berg, H., 2006. Does immigration affect labor demand? Model and test. Research in Labour Economics, 24, pp.135-166.

Bodvarsson, Ö.B., Van den Berg, H.F. and Lewer, J.J., 2008. Measuring immigration's effects on labor demand: A reexamination of the Mariel Boatlift. Labour Economics, 15(4), pp.560-574.

Borjas, G.J., 2003. The labor demand curve is downward sloping: Reexamining the impact of immigration on the labor market. The quarterly journal of economics, 118(4), pp.1335-1374.

Borjas, G.J., 2014. Immigration economics. Harvard University Press.

Borjas, G.J., 2017. The wage impact of the Marielitos: A reappraisal. ILR Review, 70(5), pp.1077-1110.

Brown, Richard P. C., and Eliana Jimenez. (2007). 'Estimating the Net Effects of Migration and Remittances on Poverty and Inequality: Comparison of Fiji and Tonga.' UNU-WIDER Research Paper 2007/23, United Nations University World Institute for Development Economics Research, Helsinki.

Burchardi, K.B., Chaney, T. and Hassan, T.A., 2016. Migrants, ancestors, and investments (No. w21847). National Bureau of Economic Research.

Butcher, K.F. and Piehl, A.M., 1998. Cross-city evidence on the relationship between immigration and crime. Journal of Policy Analysis and Management: The Journal of the Association for Public Policy Analysis and Management, 17(3), pp.457-493.

Card, D., 1990. The impact of the Mariel boatlift on the Miami labor market. ILR Review, 43(2), pp.245-257.

Card, D., 2009. Immigration and inequality. American Economic Review, 99(2), pp.1-21.

Carrington, W. J., and P. J. F. De Lima, 1996. "The impact of 1970s repatriates Africa on the Portuguese labor market." Industrial and Labor Relations Review 49:2 (1996):, 1996330 347.

Cattaneo, C., Fiorio, C.V. and Peri, G., 2015. What happens to the careers of European workers when immigrants "take their jobs"? Journal of Human Resources, 50(3), pp.655693.

Cattaneo, C., Fiorio, C.V. and Peri, G., 2015. What happens to the careers of European workers when immigrants "take their jobs"? Journal of Human Resources, 50(3), pp.655693. 
Cecchetti, Stephen and Kim Schoenholtz (2018), "The stubbornly high cost of remittances", VoxEU, 27 March 2018.

Clemens, M.A., Montenegro, C.E. and Pritchett, L., 2019. The place premium: Bounding the price equivalent of migration barriers. Review of Economics and Statistics, 101(2), pp.201213.

Clements, M.B.J., 2015. The fiscal consequences of shrinking populations. International Monetary Fund.

Cohen, L., Gurun, U.G. and Malloy, C., 2017. Resident networks and corporate connections: Evidence from World War II internment camps. The Journal of Finance, 72(1), pp.207-248.

Conde-Ruiz, J.I., García, J.R. and Navarro, M., 2008. Inmigración y crecimiento regional en España. Colección estudios económicos, pp.09-08.

Cortes, P. and Tessada, J., 2011. Low-skilled immigration and the labor supply of highly skilled women. American Economic Journal: Applied Economics, 3(3), pp.88-123.

D'Amuri, F. and Peri, G., 2014. Immigration, jobs, and employment protection: evidence from Europe before and during the great recession. Journal of the European Economic Association, 12(2), pp.432-464.

Davies, S. (2008). 'Remittances as insurance for household and community shocks in an agricultural economy: The case of rural Malawi,' Unpublished manuscript. Available online: http://siteresources.worldbank.org/INTTRADERESEARCH/Resources/5448241323963330969/8322197-1323963818018/Davies.pdf.

De Brauw, A., Mueller, V. and Woldehanna, T. (2013). 'Motives to remit: Evidence from tracked internal migrants in Ethiopia', World Development, 50, pp. 13-23.

Docquier, F., Dao, T.H., Parsons, C. and Peri, G., 2018. Migration and development: Dissecting the anatomy of the mobility transition. Journal of Development Economics, 132, pp.88-101.

Docquier, F., Ozden, Ç. and Peri, G., 2014. The labor market effects of immigration and emigration in OECD countries. The Economic Journal, 124(579), pp.1106-1145.

Dustmann, C. and Frattini, T., 2014. The fiscal effects of immigration to the UK. The economic journal, 124(580), pp.F593-F643.

Dustmann, C. and Görlach, J.S., 2015. Selective out-migration and the estimation of immigrants' earnings profiles. In Handbook of the Economics of International Migration (Vol. 1, pp. 489-533). North-Holland.

Dustmann, C. and Görlach, J.S., 2016. The economics of temporary migrations. Journal of Economic Literature, 54(1), pp.98-136.

Dustmann, C. and Preston, I.P., 2007. Racial and economic factors in attitudes to immigration. The BE Journal of Economic Analysis \& Policy, 7(1).

Dustmann, C., 1996. The social assimilation of immigrants. Journal of population economics, 9(1), pp.37-54.

Ehrlich, I., 1973. Participation in illegitimate activities: A theoretical and empirical investigation. Journal of Political Economy, 81(3), pp.52 1-565. 
Fagen, P. (2006). 'Remittances in crises: A Haiti case study,' Humanitarian Policy Group Background Paper, London: ODI.

Fairlie, R.W. and Lofstrom, M., 2015. Immigration and entrepreneurship. In Handbook of the economics of international migration (Vol. 1, pp. 877-911). North-Holland.

Flavin, P., Pacek, A.C. and Radcliff, B., 2011. State intervention and subjective well-being in advanced industrial democracies. Politics \& Policy, 39(2), pp.251-269.

Foged, M. and Peri, G., 2016. Immigrants' effect on native workers: New analysis on longitudinal data. American Economic Journal: Applied Economics, 8(2), pp.1-34.

Glitz, A, 2012. "The labor market impact of immigration: A quasi-experiment exploiting immigrant location rules in Germany." Journal of Labor Economics 30:1 (2012): 175-213.

Grogger, J. and Hanson, G.H., 2011. Income maximization and the selection and sorting of international migrants. Journal of Development Economics, 95(1), pp.42-57.

Halliday, T. (2006). 'Migration, risk and liquidity constraints in El Salvador', Economic Development and Cultural Change, 54, pp. 893-925.

Helbling, M., Simon, S. and Schmid, S.D., 2020. Restricting immigration to foster migrant integration? A comparative study across 22 European countries. Journal of ethnic and migration studies, pp.1-22.

Ho, G. and Shirono, K., 2015. The Nordic labor market model and the role of labor mobility and migration. Режим доступу: https://www. imf. org/external/pubs/ft/wp/2015/wp 15254 . pdf.

Ho, G. and Turk-Ariss, R., 2018. The Labor Market Integration of Migrants in Europe: New Evidence from Micro Data. International Monetary Fund.

Hunt, J, 1992. "The impact of the 1962 repatriates from Algeria on the French labor market." Industrial and Labor Relations Review 45:3 (1992): 556-572.

IMF, 2016. Kyrgyz Republic: Selected Issues. IMF Country Report No. 16/56

IMF, 2016. World Economic Outlook. Chapter 4: Spillovers from China's Transition and from Migration.

International Monetary Fund, 2020. World Economic Outlook: The Great Lockdown. Chapter 4: The Macroeconomic Effects of Global Migration. Washington DC, April.

Jaumotte, M.F., Koloskova, K., and Saxena, M.S.C., 2016. Impact of migration on income levels in advanced economies. International Monetary Fund.

Javorcik, B.S., Özden, Ç., Spatareanu, M. and Neagu, C., 2011. Migrant networks and foreign direct investment. Journal of development economics, 94(2), pp.231-241.

Kerr, W.R. and Lincoln, W.F., 2010. The supply side of innovation: H-1B visa reforms and US ethnic invention. Journal of Labor Economics, 28(3), pp.473-508.

Koczan, Zs. (2016). 'Remittances during crises: Evidence from ex-Yugoslavia, Economics of Transition, 24(3), pp. 507-533.

Koczan, Zsoka, and Franz Loyola. (2018). 'How do migration and remittances affect inequality? A case study of Mexico’ IMF Working Paper, No. 18/136, 2018. 
Kossoudji, S.A. and Cobb-Clark, D.A., 2002. Coming out of the shadows: Learning about legal status and wages from the legalized population. Journal of Labor Economics, 20(3), pp.598-628.

Kugler, A., and M. Yuksel, 2008. Effects of Low-Skilled Immigration on US Natives: Evidence from Hurricane Mitch. IZA Discussion Paper No. 3670, 2008.

Lozano, F. and Sørensen, T.A., 2011. The Labor Market Value to Legal Status.

Margolis, David, Luis Miotti, El Mouhoub Mouhoud, Joël Oudinet. (2013). 'To Have and Have Not': Migration, Remittances, Poverty, and Inequality in Algeria.' IZA Discussion Paper 7747, Institute for the Study of Labor, Bonn.

Mastrobuoni, G. and Pinotti, P., 2011. Migration restrictions and criminal behavior: Evidence from a natural experiment.

Maystadt, J.-F., and P. Verwimp, 2014. "Winners and losers among a refugee-hosting population." Economic Development and Cultural Change 62:4 (2014): 769-809.

McKenzie, D. and H. Rapoport 2007. 'Network effects and the dynamics of migration and inequality: Theory and evidence from Mexico.' Journal of Development Economics, 84(1), pp. 1-24.

Milanovic, B., 2016. Global inequality: A new approach for the age of globalization. Harvard University Press.

Miles, T.J. and Cox, A.B., 2014. Does immigration enforcement reduce crime? Evidence from secure communities. The Journal of Law and Economics, 57(4), pp.937-973.

Mohapatra, S., Joseph, G. and Ratha, D. (2009). 'Remittances and natural disasters: Ex-post response and contribution to ex-ante preparedness,' Policy Research Working Paper Series No. 4972, Washington, DC: The World Bank.

Möllers, Judith and Wiebke Meyer. (2014). 'The Effects of Migration on Poverty and Inequality in Rural Kosovo.' IZA Journal of Labor \& Development 3 (16).

Mughal, Mazhar, and Amar Iqbal Anwar. (2012). 'Remittances, Inequality and Poverty in Pakistan: Macro and Microeconomic Evidence.' CATT Working Paper 2, Centre d'Analyse Théorique et de Traitement des données économiques, Cedex.

OECD- European Commission, 2018. Settling in 2018: Indicators of Immigrant Integration OECD, 2013. International Migration Outlook 2013. OECD Publishing

Olney, W.W., 2013. Immigration and firm expansion. Journal of regional science, 53(1), pp.142-157.

Omar Mahmoud, T., Rapoport, H., Steinmayr, A., and Trebesch, C., 2013. The effect of labor migration on the diffusion of democracy: evidence from the former Soviet Republic. Orrenius, P., 2017. New Findings on the Fiscal Impact of Immigration in the United States. Özden, Ç., and Wagner, M., 2014. Immigrant versus natives? Displacement and job creation. The World Bank.

Parsons, C. and Vezina, P., 2016. Migrant Networks and Trade: The Vietnamese Boat People as a Natural Experiment" forthcoming. The Economic Journal. 
Peri, G. and Sparber, C., 2009. Task specialization, immigration, and wages. American Economic Journal: Applied Economics, 1(3), pp.135-69.

Peri, G. and Yasenov, V., 2017. The labor market effects of a refugee wave: Applying the synthetic control method to the Mariel Boatlift. NBER Working Paper No. 21801.

Peri, G., 2012. The effect of immigration on productivity: Evidence from US states. Review of Economics and Statistics, 94(1), pp.348-358.

Peri, G., 2014. Do immigrant workers depress the wages of native workers?. IZA World of Labor.

Peri, G., Rury, D., and Wiltshire, J., 2020. The Economic Impact of Migrants from Hurricane Maria.

Pinotti, P., 2017. Clicking on heaven's door: The effect of immigrant legalization on crime. American Economic Review, 107(1), pp.138-68.

Rother, M.B., Pierre, M.G., Lombardo, D., Herrala, R., Toffano, M.P., Roos, M.E., Auclair, M.A.G. and Manasseh, M.K., 2016. The economic impact of conflicts and the refugee crisis in the Middle East and North Africa. International Monetary Fund.

Schmitz, Kai and Isaku Endo (2011), “Lowering the cost of sending money home," Finance and Development, June 2011.

Stark, Oded, J. Edward Taylor, and Shlomo Yitzhaki. (1988). 'Migration, Remittances and Inequality: A Sensitivity Analysis using the Extended Gini Index.' Journal of Development Economics 28:309-22.

Suleri, A. Q. and Savage, K. (2006). 'Remittances in crises: A case study from Pakistan,' Humanitarian Policy Group Background Paper, London: Overseas Development Institute.

Taylor, J. Edward, Richard Adams, Jorge Mora, and Alejandro López-Feldman. (2009).

'Remittances, Inequality and Poverty: Evidence from Rural Mexico.' Available at http://essays.ssrc.org/acrossborders/wp-content/uploads/2009/08/ch6.pdf.

Vandor, P. and Franke, N., 2016. Why are immigrants more entrepreneurial? Harvard Business Review, 27.

Weiss Fagen, P. and Bump, M. N. (2005). 'Remittances in conflict and crises: How remittances sustain livelihoods in war, crises, and transitions to peace,' International Peace Academy Policy Paper, Washington, DC: International Peace Academy. Georgetown University.

World Bank, 2006. Global Economic Prospects: Economic Implications of Remittances and Migration. Washington, DC: The World Bank.

World Bank, 2014. International Migration and Development in East Asia and the Pacific. Washington, DC: The World Bank.

World Bank, 2018. Moving for Prosperity Global Migration and Labor Markets. Washington, DC: The World Bank.

World Bank, 2019. Leveraging Economic Migration for Development. Washington, DC: The World Bank.

Wu, T., 2006. 'The role of remittances in crisis: An Aceh research study,' Humanitarian Policy Group Background Paper, London: ODI. 